Article

\title{
Occurrence, Classification and Formation Mechanisms of the Organic-Rich Clasts in the Upper Paleozoic Coal-Bearing Tight Sandstone, Northeastern Margin of the Ordos Basin, China
}

\author{
Guanqun Yang ${ }^{1,2,3}$, Wenhui Huang ${ }^{1,2,3, *}$, Jianhua Zhong ${ }^{4}$ and Ningliang Sun 4 \\ 1 School of Energy Resources, China University of Geosciences (Beijing), Beijing 100083, China; \\ yq19890923@126.com \\ 2 Key Laboratory of Marine Reservoir Evolution and Hydrocarbon Enrichment Mechanism, Ministry of \\ Education, Beijing 100083, China \\ 3 Beijing Key Laboratory of Unconventional Natural Gas Geological Evaluation and Development \\ Engineering, Beijing 100083, China \\ 4 School of Geosciences, China University of Petroleum, Qingdao 266580, China; \\ zhongjianhua57@163.com (J.Z.); sunningliangll@163.com (N.S.) \\ * Correspondence: huangwh@cugb.edu.cn
}

Received: 24 April 2020; Accepted: 23 May 2020; Published: 27 May 2020

\begin{abstract}
The detailed characteristics and formation mechanisms of organic-rich clasts (ORCs) in the Upper Paleozoic tight sandstone in the northeastern margin of the Ordos Basin were analyzed through 818-m-long drilling cores and logging data from 28 wells. In general, compared with soft-sediment clasts documented in other sedimentary environments, organic-rich clasts in coal-bearing tight sandstone have not been adequately investigated in the literature. ORCs are widely developed in various sedimentary environments of coal-bearing sandstone, including fluvial channels, crevasse splays, tidal channels, sand flats, and subaqueous debris flow deposits. In addition to being controlled by the water flow energy and transportation processes, the fragmentation degree and morphology of ORCs are also related to their content of higher plants organic matter. The change in water flow energy during transportation makes the ORCs show obvious mechanical depositional differentiation. Four main types of ORC can be recognized in the deposits: diamictic organic-rich clasts, floating organic-rich clasts, loaded lamellar organic-rich clasts, and thin interlayer organic-rich clasts. The relationship between energy variation and ORCs deposition continuity is rarely studied so far. Based on the different handling processes under the control of water flow energy changes, we propose two ORCs formation mechanisms: the long-term altering of continuous water flow and the short-term water flow acting triggered by sudden events.
\end{abstract}

Keywords: coal-bearing tight sandstone; organic-rich clasts; occurrence; classifications; formation mechanisms; Ordos Basin

\section{Introduction}

The soft-sediment clasts (SSCs), as aggregations of the fine sediments formed at the syngenetic sedimentary stage, are often dispersedly preserved in the water-transported sandy hosting sediments [1,2]. SSCs are widely developed in a variety of modern and ancient sedimentary settings, including glacial, alluvial, fluvial, estuarine, coastal, shoreline and deep-water environments [3-12]. The terms used by the researchers to characterize sedimentary features are varied, for instance clay balls [3], armored or unarmored mud balls [4,7,13-18], mud pebbles [4], mud clasts $[6,8,12,19,20]$, rip-up clasts [21-25], blocks [26-28], intraformational clasts [29]. SSCs are also commonly regarded 
as the palaeoenvironmental indicators to obtain geological information on clasts transportation, deposition and deformation processes, and regional-scale palaeoenvironmental setting [2,30]. Therefore, numerous targeted researches have been carried out on the morphology, classification, formation and transportation mechanism of different SSCs under particular settings [1,12]. In addition to the above types, a special kind of soft sediment clasts is developed in coal-bearing strata, consisting of coaly fragments, carbonaceous mud clasts and coalified plant remains, etc., typically marked by enriching in organic matter. Here, the term "organic-rich clasts (ORCs)" is used for describing this outstanding feature.

As early as the beginning of the last century, the organic-rich clasts in coal-bearing strata had been observed [31]. Since then, the organic-rich clasts were widely found in the coal-bearing strata of the major coal-bearing basins in the world, mostly distributed in the sandstone either close to or far above the top of the coal seams [31-37]. Researchers often interpreted the significance of the organic-rich clasts from the perspective of coal petrology, including morphology, composition, degree of thermal evolution, time of coalification [37-39]. In recent years, coal-derived gas (especially tight sandstone gas) has been developed on a large commercial scale [40,41]. For example, in the Upper Paleozoic tight sandstone gas-bearing strata of the Ordos Basin in China, several tight sandstone gas fields with a reserve of over $1 \times 10^{8} \mathrm{~m}^{3}$ have been discovered, like the Sulige gas field [42,43]. Meanwhile, the influence of organic-rich clasts in the coal-bearing strata on tight sandstone gas reservoirs has also received attention, involving diagenesis, property and gas accumulation [20,44,45]. Moreover, it must also be mentioned that organic-rich clasts in sandstone (mainly terrestrial higher plant) can supply abundant hydrocarbon [46,47]. Despite these geological implications, however, few studies have ever focused on the formation and transportation mechanisms of organic-rich clast in the coal-bearing sandstone strata.

Taking the Upper Paleozoic coal-bearing tight sandstone formation in the northeast margin of the Ordos Basin as an example, the present paper has three main objectives: (1) to identify the morphology and distribution of organic-rich clasts in different sedimentary environments; (2) to investigate the classification and sedimentary sequence of organic-rich clasts in the coal-bearing strata; (3) to systematically analyze the formation mechanisms of organic-rich clasts in the coal-bearing tight sandstone. The results of this paper will be conducive to deepen the understanding of organic-rich clasts.

\section{Geological Setting}

The Ordos Basin, located in the western part of the Sino-Korean plate (Figure 1A), covering an area of about $25 \times 10^{4} \mathrm{~km}^{2}$, is an intracratonic basin developed from the Archaean to Early Proterozoic [48,49]. As a large polycyclic superimposed basin, the Ordos Basin underwent a multi-stage tectonic movement during a long geological history. According to the current tectonic features of the Ordos Basin, six tectonic units were identified, which are composed of the Yimeng uplift in the north, the Weibei uplift in the south, the Western margin thrust belt and the Tianhuan depression in the west, the Jinxi fault-fold belt in the east, and the Shanbei slope in the central region [50]. The study area is located in the northeastern margin of the Ordos Basin, presenting a gentle monoclinal structure towards the west on the whole (Figure 1B). In addition, many small folds and faults have developed on it [51].

The Upper Paleozoic strata in the Ordos Basin consist of the Upper Carboniferous Benxi Formation, the Lower Permian Taiyuan Formation and the Shanxi Formation, the Middle Permian Lower and Upper Shihezi Formation, and the Upper Permian Shiqianfeng Formation (Figure 1C, D and Figure 2). Benxi Formation, Taiyuan Formation, and Shanxi Formation are coal-bearing strata, which are the interest intervals of this study. In the Late Carboniferous-Early Permian, a set of coal-bearing sedimentary formation deposited based on the Ordovician paleo crust of weathering with the Yinshan paleo-land supplying sources [52]. From the Benxi Formation to the Taiyuan Formation, a barrier coastal sedimentary system developed in the background of the epeiric sea, mainly including barrier islands, lagoons, tidal flats, and carbonate platforms [53]. Nevertheless, the fluvial-delta sedimentary system developed in the Shanxi Formation [54-56]. A warm and humid climate and lush vegetation 
promoted the development of organic-rich sediments composed of coal, carbonaceous mudstone and dark mudstone, with a cumulative thickness of $>200 \mathrm{~m}$ [57]. Moreover, the coal-bearing sequences are the main source rock characterized by a high content of thermally mature total organic carbon, providing a sufficient source of gas for the tight sandstone gas reservoirs in the Upper Paleozoic [58,59]. Besides, barrier island sandstone and channel sandstones constitute the favorable reservoirs adjacent to the source rocks [60].

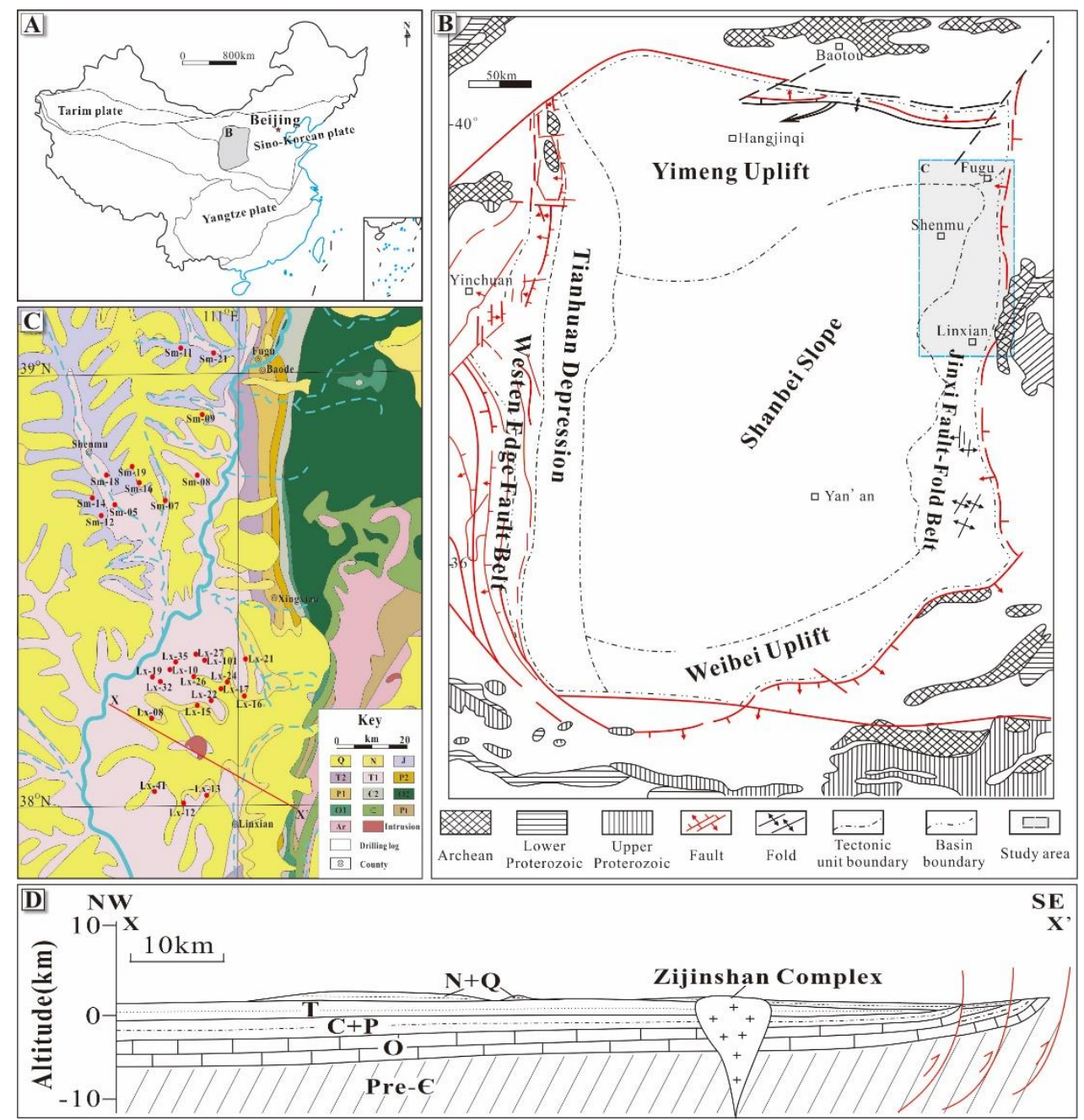

Figure 1. (A) Location of the Ordos Basin in simplified tectonic map of China. (B) Tectonic division of the Ordos Basin (modified after Luo et al.) [61], showing the location of the study area. (C) Schematic geological map of the northeastern margin of the Ordos Basin showing the drilling sites. (D) Sketch cross section through the south of study area (modified from Liao et al.) [62], position located on (B). 


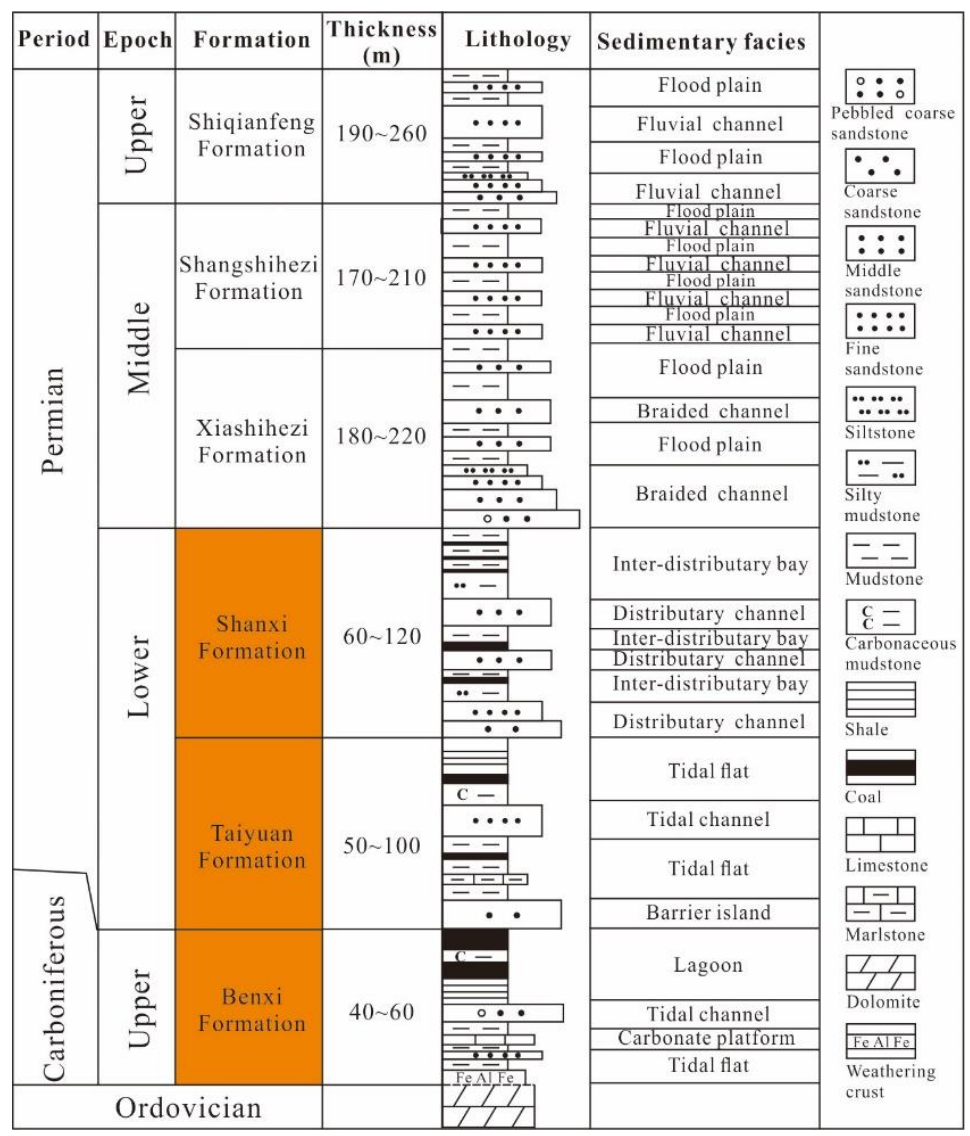

Figure 2. Lithochronostratigraphical column of the Upper Paleozoic strata in the study area. Here, we described the development characteristics of organic-rich clasts in coal-bearing sandstones in detail through core observation, and the descriptions contain lithology, morphology, distribution, and deformation. Thirty-six typical hand specimens were selected from the cores to prepare thin sections; meanwhile, the microscopic feature information of ORC was captured by the ZEISS optical microscope. Twelve whole-rock polished blocks were prepared to carry out maceral analysis. Maceral analysis was performed under a Zeiss Axio imager microscope equipped with an oil immersion objective and a white incident and a blue light source where $>800$ points were considered for each sample. Maceral was classified by the ICCP (International Committee for Coal Petrology) System 1994 [63-65]. The lithofacies codes are named according to [66]; some codes are added and modified following [67]. Based on the facies data derived from core descriptions and logging interpretations, a series of detailed comparative analysis was made on the organic-rich clasts, in order to find out the origins and control factors of ORCs developed in different sedimentary environments.

\section{Methodology}

A total of 28 exploration wells were selected as research objects in this study, drilled from 2013 to 2017 by the China United Coalbed Methane Corporation. In total, more than 818-m-long conventional cores were received from 28 wells, diffusely covering the developed intervals of the tight sandstone gas reservoirs in coal-bearing formation; additionally, all the wells were logged with a set of comprehensive wireline surveys and cuttings. The cores have been macroscopically examined and described at $1-\mathrm{cm}$ scale to obtain information on lithology, sedimentary structures, and geometric features of the organic-rich clasts. Samples have been collected from the shallow marine shelf, barrier coast and fluvial-delta deposits in all the three coal-bearing formations, thus providing sufficient geological information to undertake a comprehensive study of ORCs. 


\section{Results}

Eleven types of lithofacies related to organic-rich clasts are recognized within the Carboniferous-Permian coal-bearing strata (Table 1). These have been divided into 5 types of facies associations standing for different sedimentary processes and settings, which have been identified in cores in conjunction with the interpretation of logging curves. These facies associations are mainly interpreted as channels (fluvial channels and delta distributary channels), crevasse splays, sand flats, tidal channels, and subaqueous debris flow deposits. The occurrence of organic-rich clasts will be described in detail below, representing the variation of water-flow energy during sediment transport.

Table 1. Main lithofacies of the Upper Paleozoic Benxi, Taiyuan and Shanxi Formations in the northeastern margin of the Ordos Basin.

\begin{tabular}{|c|c|c|c|c|}
\hline $\begin{array}{l}\text { Facies } \\
\text { Code }\end{array}$ & Lithofacies & Description & $\begin{array}{l}\text { Depositional } \\
\text { Environment }\end{array}$ & Example \\
\hline $\mathrm{Gm}$ & $\begin{array}{l}\text { Matrix-supported } \\
\text { conglomerate }\end{array}$ & $\begin{array}{l}\text { Mixed of gravels, sands and } \\
\text { detrital clays, mainly gravels, } \\
\text { poorly sorted and angular, } \\
\text { weak grading, massive } \\
\text { bedding, erosional base, thin } \\
\text { thickness }\end{array}$ & $\begin{array}{l}\text { Fluvial channel, } \\
\text { crevasse splay }\end{array}$ & \\
\hline Gc & $\begin{array}{l}\text { Clast-supported } \\
\text { conglomerate }\end{array}$ & $\begin{array}{l}\text { Mainly gravels, with little } \\
\text { matrix, sub-angular to } \\
\text { sub-rounded, moderate sorted, } \\
\text { graded bedding, erosional base, } \\
\text { ranging in thickness from a few } \\
\text { centimeters to } 20 \mathrm{~cm}\end{array}$ & $\begin{array}{l}\text { Fluvial channel, } \\
\text { distributary } \\
\text { channel, tidal } \\
\text { channel }\end{array}$ & \\
\hline $\mathrm{Sm}$ & $\begin{array}{l}\text { Medium- to } \\
\text { coarse-grained } \\
\text { sandstone }\end{array}$ & $\begin{array}{l}\text { Moderate to well sorted and } \\
\text { rounded, massive bedding, } \\
\text { structureless, may be pebbly, }\end{array}$ & $\begin{array}{l}\text { Fluvial channel, } \\
\text { distributary } \\
\text { channel, tidal } \\
\text { channel, debris } \\
\text { flow deposits, } \\
\text { crevasse splay }\end{array}$ & \\
\hline St & $\begin{array}{l}\text { Fine- to } \\
\text { coarse-grained } \\
\text { sandstone }\end{array}$ & $\begin{array}{l}\text { Trough cross-bedding, } \\
\text { moderate sorted }\end{array}$ & $\begin{array}{l}\text { Fluvial channel, } \\
\text { distributary } \\
\text { channel, tidal } \\
\text { channel }\end{array}$ & \\
\hline Sp & $\begin{array}{l}\text { Fine- to } \\
\text { coarse-grained } \\
\text { sandstone }\end{array}$ & $\begin{array}{l}\text { Planar cross-bedding, well } \\
\text { sorted and rounded }\end{array}$ & $\begin{array}{l}\text { Fluvial channel, } \\
\text { distributary } \\
\text { channel }\end{array}$ & \\
\hline
\end{tabular}


Table 1. Cont.

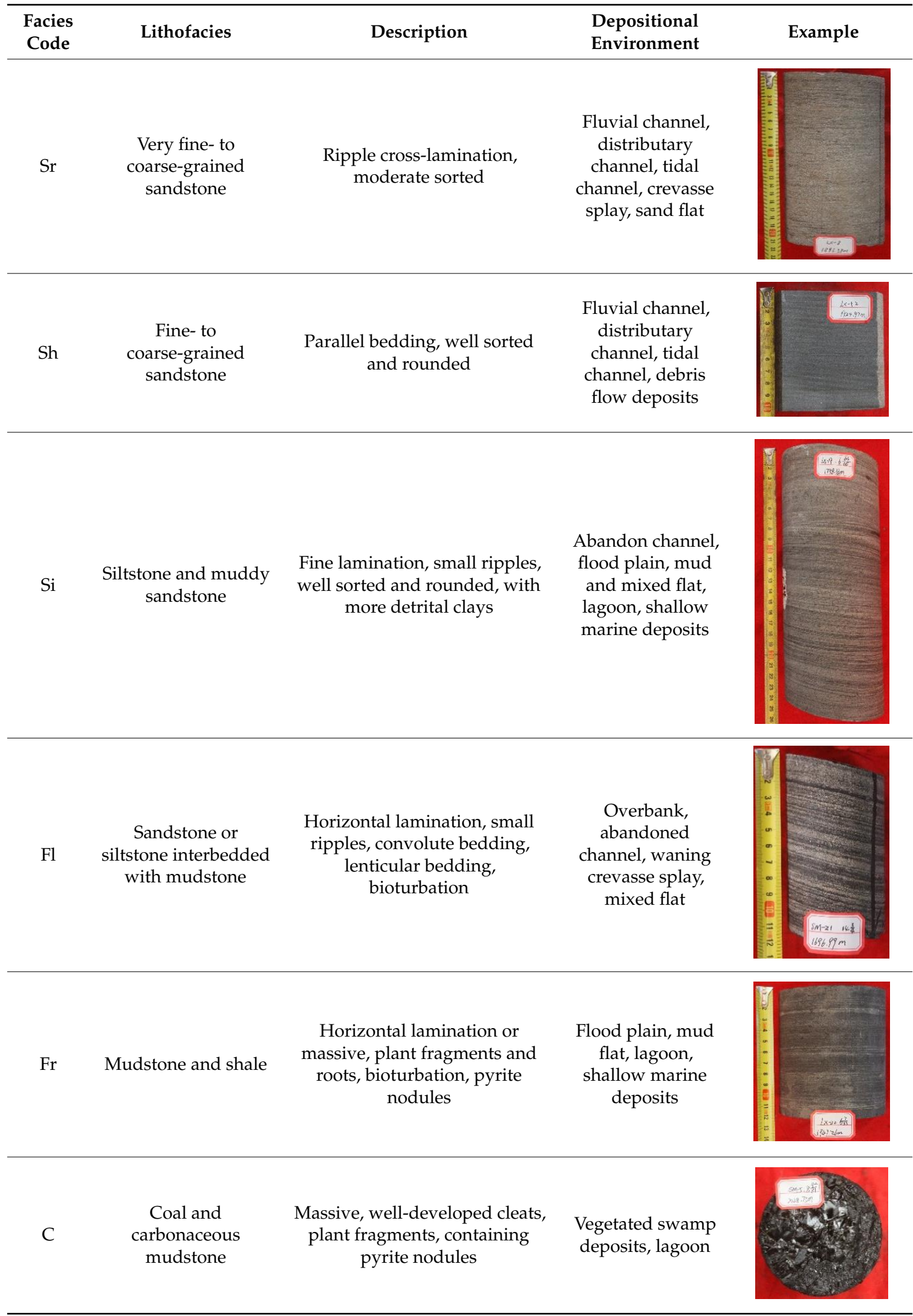

The organic-rich clasts are widely distributed in the coal-bearing tight sandstones of Benxi Formation, Taiyuan Formation and Shanxi Formation in the study area. The lithology of ORCs 
identified in the core includes carbonaceous clasts, carbonaceous mudstone clasts, dark mudstone clasts, shale clasts, and plant fragments (Figure 3A-D). In terms of color, the organic-rich clasts are mostly black or grayish black, and easy to dye the hosting sandstone. Moreover, the associated pyrite, commonly identified in the core hand specimens, is a characteristic mineral formed from organic-rich clasts in a local reducing microenvironment during diagenesis (Figure 3E). The shapes of ORCs are varied, including blades, discs, plate strips, tearing chips and irregular forms. The grain size is generally gravel size, with a maximum of more than $10 \mathrm{~cm}$. Although strongly deformed, the long axes of most ORCs are parallel or sub-parallel to the stratum (Figure 3A,B).
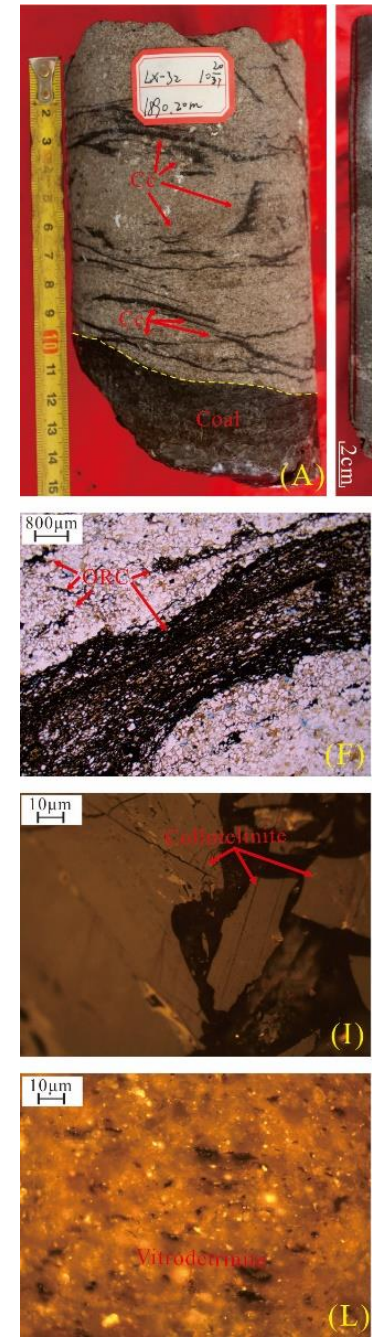
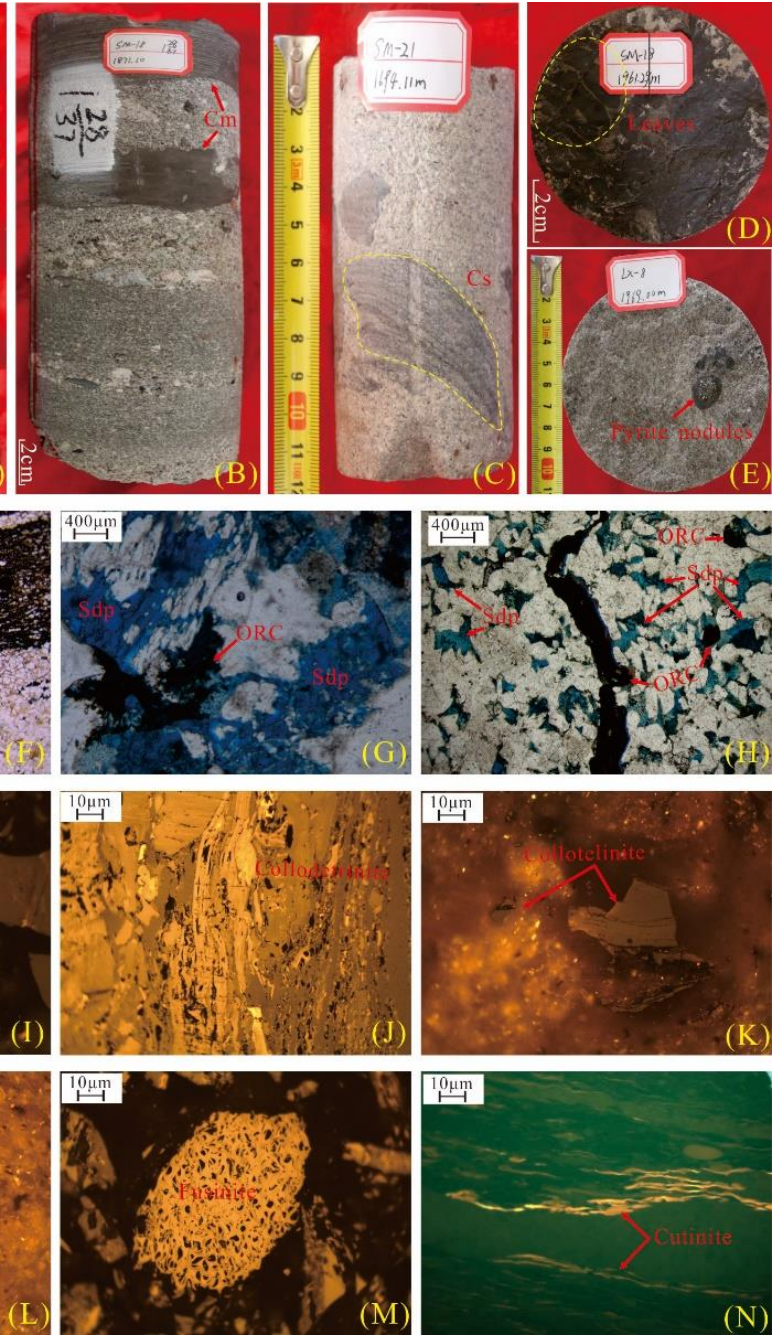

Figure 3. Typical photographs of core (A-E), thin sections (F-H) and polished blocks (I-N) of ORC in the studied coal-bearing sandstones. Abbreviations: $\mathrm{Cc}_{\mathrm{c}}=$ Carbonaceous clasts, $\mathrm{Cm}=$ Mudstone clasts, $\mathrm{Cs}=$ Shale clasts, Sdp = Secondary dissolution pores, PPL = plane-polarized light, $\mathrm{RL}=$ reflected light. (A) Scattered coaly clasts with plastic deformation (LX-32, 1890.20 m). (B) Cobble dark mudstone clasts in the conglomerate (SM-18, 1871.10 m). (C) Shale clasts showing clear bedding (SM-21, $1694.11 \mathrm{~m}$ ). (D) Plant leaves with clear outlines (SM-18, 1961.29 m). (E) Associated pyrite nodules of ORC (LX-8, 1969 m). (F) Thin-bedded ORC containing fine-grained sediments (PPL, LX-44, $2063.12 \mathrm{~m}$ ). (G) Secondary dissolution pores of feldspars around the ORC (PPL, SM-4, $2134.1 \mathrm{~m}$ ). (H) A strip of ORC with secondary dissolution pores (PPL, LX-103, 1721.5 m). (I) Homogenous collotelinite (RL, SM-19, $2116.52 \mathrm{~m}$ ). (J) Cementing collodetrinite (RL, LX-35, 1922.54 m). (K) Blocky collotelinite and vitrodetrinite (RL, SM-20, $2072.98 \mathrm{~m}$ ). (L) Scattered vitrodetrinite in the matrix (RL, SM-19, $2083.1 \mathrm{~m}$ ). (M) Clumpy pyro-fusinite and scattered vitrinite (RL, LX-33, 1732.1 m). (N) Cutinite with yellow fluorescence (fluorescence-mode, SM-7, $1872.80 \mathrm{~m}$ ). 
Under the microscope, ORCs with small particle size can also be observed widely, which usually show a characteristic of compressional deformation (Figure 3F-H). The results of microscopic observation show that these ORCs are mainly composed of organic matter (OM), fine-grained sediments (Figure 3F-N), and some authigenic inorganic minerals (such as pyrite). As for the organic macerals, there are mainly vitrinite, inertinite and liptinite (Figure 3I-N). Vitrinite (type III kerogen, formed by the gelification of plant remains) is the most abundant organic component, with light gray to gray under the reflected light (Figure 3I-M). Most of these Vitrinite components are collotelinite (Figure 3I,K), collodetrinite (Figure 3J) and vitrodetrinite (Figure 3I,K-M). Vitrodetrinite, especially for the muddy ORCs, is present in the form of small discrete particles in the argillaceous matrix (Figure 3K,L). Inertinite (type-IV kerogen, derived from terrestrial plant tissues) consists of semifusinite, fusinite (Figure 3M), micrinite and inertodetrinite, and has bright white color under the reflected light. Liptinite (type-II kerogen, transformed from plant organs) is relatively rare in the analyzed samples. Only some cutinite (Figure $3 \mathrm{~N}$ ) and bituminite with obvious fluorescence characteristics are seen. Thus, it can be seen that the organic matter found in ORCs is mainly derived from terrestrial higher plants.

\subsection{Facies Association I}

\section{Description}

The facies association I is composed of Gc, Sm, St, Sp, Sr, Fl, Si, Fr, and C (Figure 4A). The sandstones are characterized by large thickness, intercalated with thin layers of siltstone and mudstone. Sedimentary structures such as basal erosional surface, massive bedding, cross-bedding, parallel bedding, and wavy bedding are well developed. Overall, the sandstones of facies association I have a fining-upward trend and a bell-shaped or jugged box-shaped logging curve (Figure 4A). On the erosion surfaces, the organic-rich clasts are most concentrated, which are poorly sorted, angular to sub-angular, and chaotic (Figure 4B,E-G,K). In the middle parts of the sand body, the floating ORC is scattered with long-axis tending towards bed-parallel orientations, mostly the shape of slender and deformed (Figure 4C,J,L). The occurrence of small granule ORC is in the form of aggregates as discontinuous or continuous laminations in the upper parts (Figure $4 \mathrm{D}, \mathrm{H}, \mathrm{I})$. These clasts are flaky, good sorted and rounded, coexisting with high fine-grained sediment content (Figure 4C,J,M).

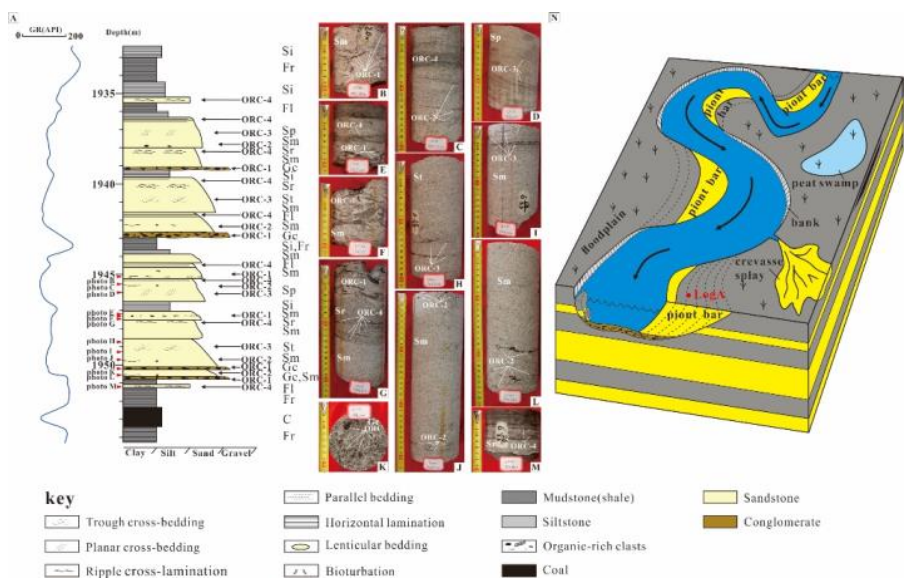

Figure 4. Sedimentary characteristics of the organic-rich clasts in the fluvial channel or distributary channel (log LX-21). (A) Schematic sedimentary succession with natural gamma-ray curve in the channel environment, showing the occurrence of ORCs in different sedimentary locations. (B-M) Typical core photographs of various ORCs occurring in different lithofacies. (C) The position of logA in the schematic diagram, showing the cause of ORC formation in channel: bank collapse and basal erosion. 
Interpretation

Thick sand sediments in the facies association I are interpreted as fluvial or distributary channel deposits (Figure $4 \mathrm{~N}$ ), while fine-grained plant remnants in flood plain and mire provide the source for the formation of ORC, all developing in the Shanxi Formation. The ORCs in sandstone are chiefly the products of either: (1) scouring of the bottom underlying semi-consolidated peat by the high energy turbulent flow; (2) lateral erosion or slumping of bank sediments triggered by the water flow (high-density turbidity or quasi-stable flow). The ORC from different parts in sandstone underwent different sedimentation. Only a small amount of produced ORCs is similarly in-situ deposited in the vicinity of the erosion surface or after short-distance rolling transport. However, most of the produced ORCs are carried away and reworked by the water flow and water-transported debris [68]. The scattered floating ORC is the result of hindered setting in a high-density turbulent flow. After intense modification and long-distance transport, the ORC breaks up into small pieces of high maturity and deposits as the energy of the water flow diminishes. The loaded ORC, in the form of weakly continuous cross-lamination, is formed under the condition of transitional to high flow regime. In the low flow regime, the fragmented ORC is shaped into the continuous lamellar aggregate.

\subsection{Facies Association II}

\section{Description}

This facies association is built up of $\mathrm{Sm}, \mathrm{Sr}, \mathrm{Si}, \mathrm{Fl}$, and C (Figure 5A). The thickness of $\mathrm{Sm}$ and $\mathrm{Sr}$ ranges between 1 and $3 \mathrm{~m}$. Sandstones have an upward-coarsening trend with sharp contacts at the bottom, as well as a finger-shaped logging curve (Figure 5A). Massive bedding, wavy bedding, and lenticular bedding can be observed. Also, roots can be recognized in the mudstone (Figure 5B,D,F,H,I). The ORC in facies association II is generally subrounded, which range in size between granule and pebble (2 64 mm; Figure 5I). The scattered clasts distribute in the massive host sandstone (Sm; Figure $5 \mathrm{H}, \mathrm{I})$. In the upper parts, wavy lamina or thin intercalated aggregates of granule ORC are often observed (Figure 5B,C).
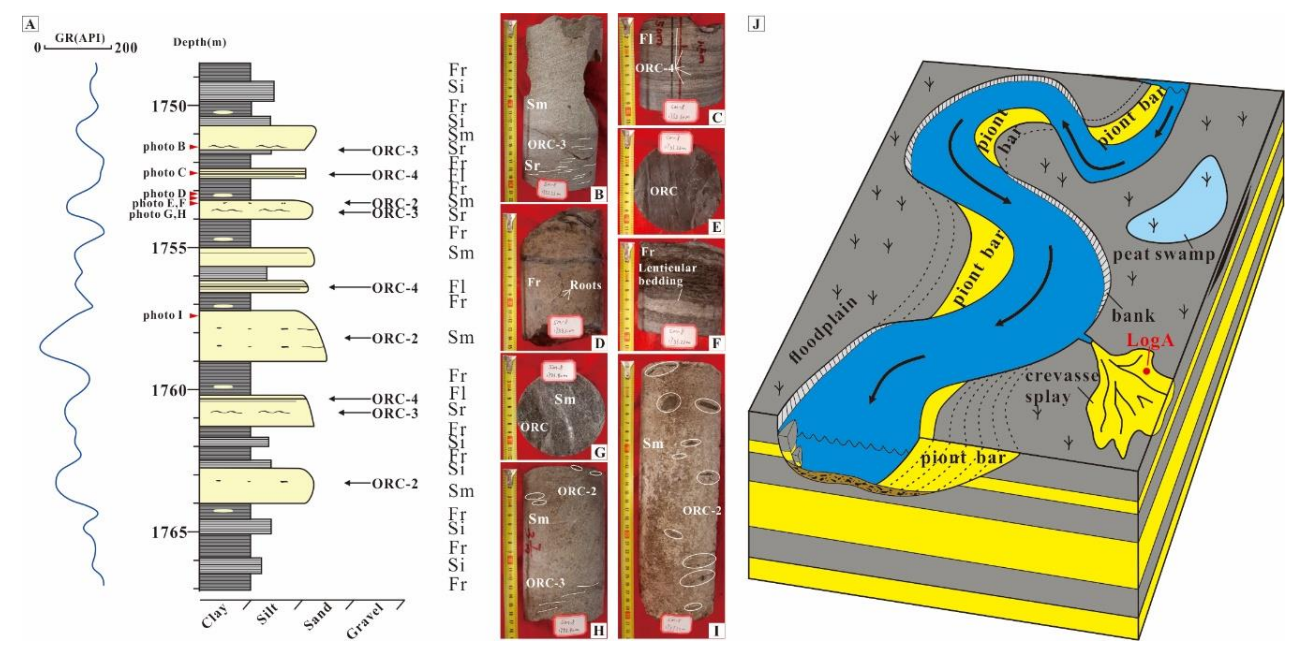

Figure 5. Sedimentary characteristics of the organic-rich clasts in the crevasse splay (log SM-8). (A) Schematic sedimentary succession and natural gamma-ray curve response of crevasse splay, showing the positions of different types of ORC. (B-I) Typical photographs of lithofacies and ORC types in the crevasse splay, including some typical sedimentary structures. (J) The location of $\log \mathrm{A}$ in the fluvial sedimentary model. 
Interpretation

Multilayered thin sandstone within this facies association developed by the channel burst in the effect of flood, identified as the crevasse splay (Figure 5J). The ORCs are derived from the organic sediments at the channel bank or the initial area in which flood flow through (Figure 5D-F). The scouring of a high-density flood, which has a fast flow rate and high energy, is the main reason for the organic-rich sediments turn into ORC in the special sedimentary environment. Due to the strong agitation of high-energy flood, ORC has a high degree of fragmentation and low structural maturity, rarely resulting in large blocks. The energy of flood decreases rapidly as a result of uncontained condition so that the ORC is deposited along with the sandy sediments after short-distance transportation. After the waters receded, the small ORC under the buoyant handling deposit as the thin layers.

\subsection{Facies Association III}

\section{Description}

The facies association III comprises $\mathrm{Gm}, \mathrm{Sm}, \mathrm{Sr}, \mathrm{Sh}, \mathrm{Fl}, \mathrm{Si}, \mathrm{Fr}$, and C (Figure 6A). The sandstone body is developed in a multi-period, with a cumulative thickness of more than $15 \mathrm{~m}$. Massive bedding, wavy bedding, and parallel bedding are main sedimentary structures. The GR logging curve is finger-shaped with some fluctuation (Figure 6A). The ORC in this facies association is characterized by variable size (granules to boulders; 2 to $>256 \mathrm{~mm}$ ) and shape, angular nature and plastic deformation. At the bottom parts of the single sand body, the clasts are disorderly accumulated with gravel or coarse sand matrix (Figure $6 \mathrm{H}$ ). The floating clasts are isolated occurring in the structureless host sandstone, with strong deformation and long-axis running parallel to bed (Figure $6 \mathrm{~B}, \mathrm{C}, \mathrm{E}-\mathrm{G}, \mathrm{I}, \mathrm{K}$ ). The small granule clasts are clustered in the form of wavy or parallel laminations (Figure 6J).
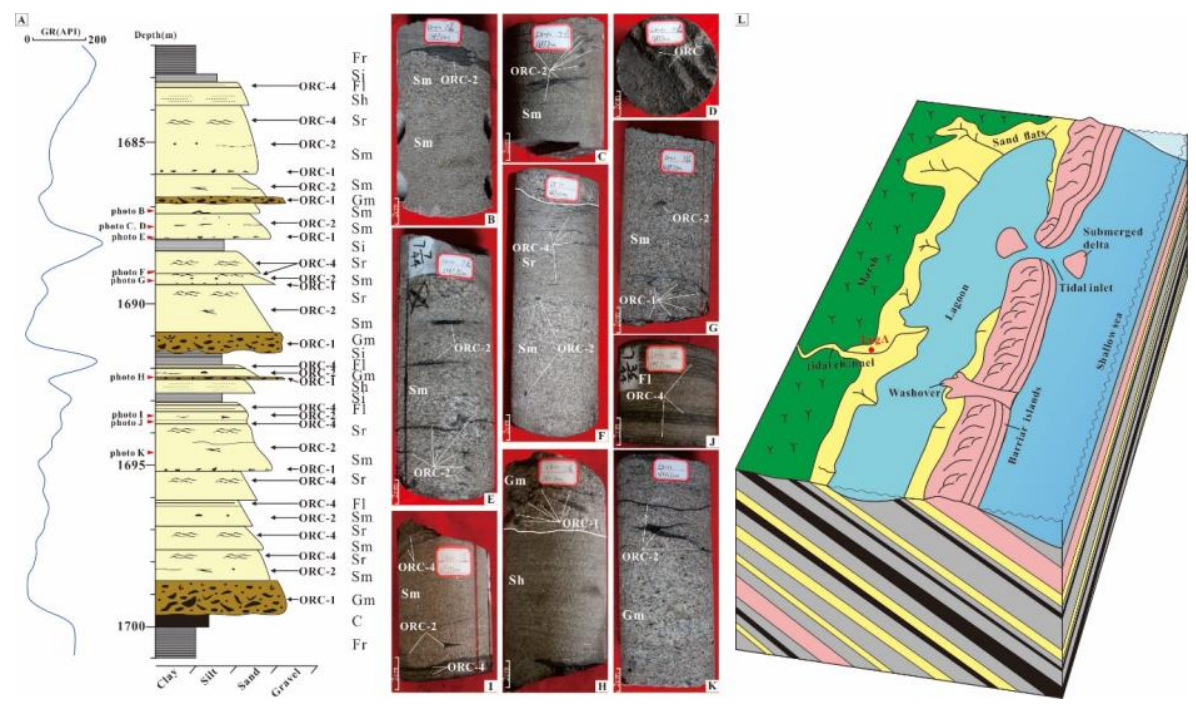

Figure 6. Sedimentary characteristics of the organic-rich clasts in the tidal channel (log LX-10). (A) Schematic sedimentary succession and the gamma-ray response of the tidal channel, including the positions of ORC. (B-K) Photos of typical lithofacies and ORC types in the tidal channel. (L) Schematic sedimentary model of barrier coast, showing the location of $\log \mathrm{A}$.

Interpretation

Thick sandstone with ORC in the sequence is interpreted as the deposits of the tidal channel (Figure 6L), mostly distributed in the upper Benxi and Taiyuan Formations. The formation of ORC, whose precursors are mainly organic-rich deposits in marsh or lagoon, is controlled by tidal processes, including basal erosion, bank erosion, and slump. With the changes in the positional relationship 
between the sun, the moon and the earth, the energy of tide has the characteristic of periodic variations. The channel-bottom deposits are flood dominated, with irregular, poorly sorted ORC mixed with gravel or coarse sand. Some large particles transported by tidal turbulence probably trapped and deposited in singles within the massive sandstone, usually resulting in heavy bending and deforming (Figure $6 \mathrm{~B}, \mathrm{~K}$ ). When the channel is ebb dominated, tidal energy gradually weakens, and the small granule ORC transported by buoyancy tends to deposit as laminations in wavy bedding sandstone (Figure 6J).

\subsection{Facies Association IV}

\section{Description}

The facies association IV is characterized by more internal structures containing $\mathrm{Sr}, \mathrm{Fl}, \mathrm{Si}, \mathrm{Fr}$, and C (Figure 7A). Fine-grained sediments and coal are developed extensively, while sandy sediments range in thickness between 0.5 and $2 \mathrm{~m}$. It is quite common to see tidal bedding such as flaser bedding, wavy bedding and lenticular bedding (Figure 7G,I-K), as well as various bioturbation structures (Figure 7F,H). The coaly fragments and plant pieces, predominantly sub-rounded to rounded, are common in the sandstone. The size of these clasts are in range from small pebbles to large cobbles (4 256 mm), occasionally boulders (Figure 7C). The most common occurrence of ORC is loaded as the wavy discontinuous lamination (Figure 7B-D).
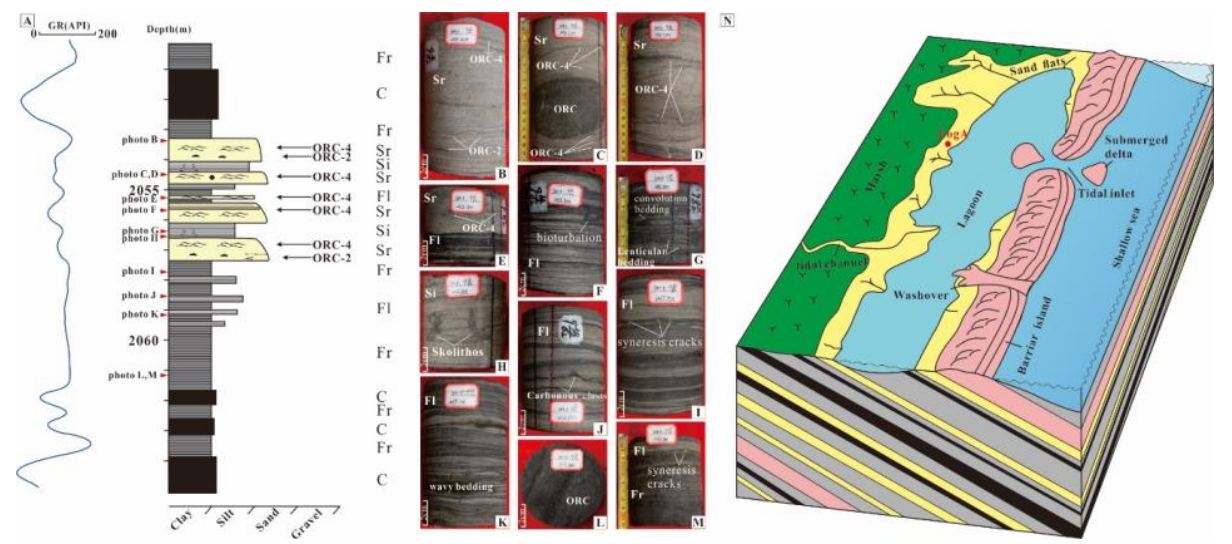

Figure 7. Sedimentary characteristics of the organic-rich clasts in the sand flat (log SM-5). (A) Schematic sedimentary succession with gamma-ray response of the sand flat, showing the occurrence of ORC. (B-J) Photos of typical lithofacies and ORC types in the sand flat, noting the sedimentary structures and bioturbation. (K) Location of $\log \mathrm{A}$ in the schematic barrier coast sedimentary model.

\section{Interpretation}

Thin wavy bedding sandstone of this facies association typifies the sand flat deposit in a tidal flat environment (Figure 7N). The thick coal seams and organic-rich mud shales (Figure 7L,M), which develop in marsh and lagoon, supply sufficient source for ORC. Two main mechanisms exist on the formation of ORC: basal erosion under the effect of tide and detachment due to synaeresis cracking (Figure 7I,M), while the transport of the broken ORC from the origin site is operated by the processes of tide currents. At the level of high tide, some large particles of ORC are trapped by sandy deposits; whereas most ORC would break up repeatedly under the action of tide currents. With the ebb of tide, the residual granule ORC would load and form into wavy lamellar aggregates. The circular coaly ORC, having a grain size of $>10 \mathrm{~cm}$ in Figure $7 \mathrm{C}$, should be a cross-section of the plant stem, which probably formed directly after depositing in the sand. 


\subsection{Facies Association $\mathrm{V}$}

\section{Description}

The fine-to-medium sandy sediments are the major component of facies association $\mathrm{V}$, while the gravels barely exist (Figure 8A). They display bed with a succession of Sm, Sh, Si, and Fr. Massive bedding and parallel bedding can be recognized generally. Moreover, the overall sandstone body develops multi-cycle erosion surfaces with fining-upward. The ORCs are mainly mudstone (shale) breccias (Figure 8C,D,F,G,I), but rarely coaly fragments and plant pieces. The intact boulder ORC retains the horizontal bedding of shale (Figure $8 \mathrm{C}, \mathrm{G}$ ). These clasts are angular to sub-rounded, with the characteristic of imbricate arrangement. The long axis of the particles is generally parallel or sub-parallel to the bedding. On the surface of basal erosion, ORCs are accumulated in variable shape and size (small pebbles to boulders; Figure 8C,F,H). In the middle parts of the single sandstone body, long strip or flaky clasts are sporadically floating in structureless sandstone (Figure 8D,E,I,J). The finely rounded pebble ORCs are deposited in weak continuous parallel laminations at the upper parts (Figure 8B).
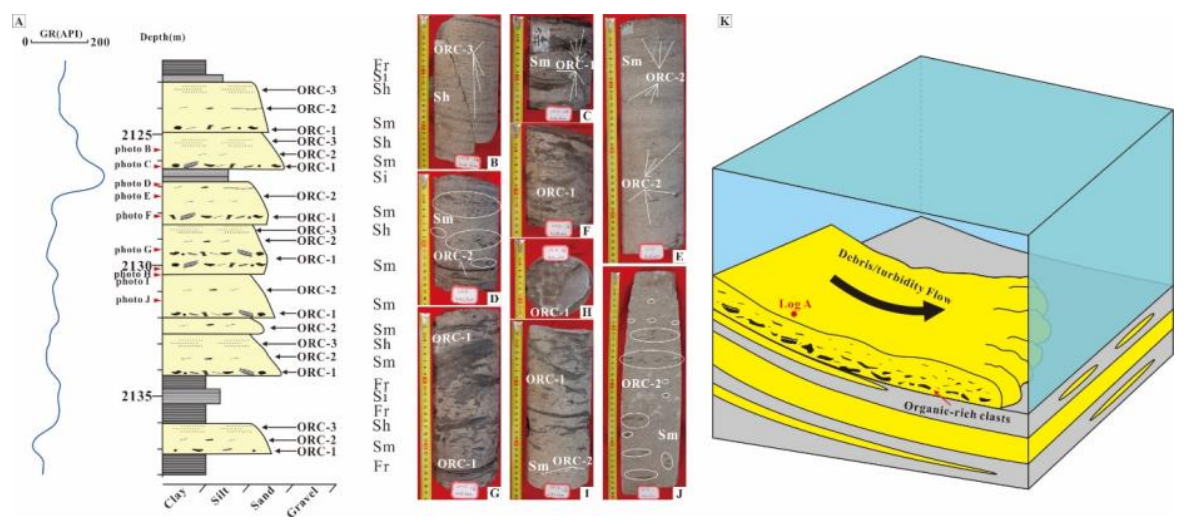

Figure 8. Sedimentary characteristics of the organic-rich clasts in the debris/turbidity flow (log LX-13). (A) Schematic sedimentary succession of the subaqueous debris/turbidity flow, occurring with high ORC content. (B-J) Photos of lithofacies and ORC types, noting the differences in the morphology and amounts of ORCs in different lithofacies. (K) Location of $\log \mathrm{A}$ in the debris/turbidity flow schematic sedimentary model.

Interpretation

Facies association $\mathrm{V}$ is limited in the lower Benxi Formation, representing the deposition of the sandy debris or turbidity flow controlled by the topography of the underlying Ordovician weathering crust locally (Figure $8 \mathrm{~K}$ ). In this case, the ORC is probably owing to flow basal erosion of muddy bottom or flow-triggered failure of muddy slope. The thick clast-supported Sm together with the presence of intact boulder ORC indicates the processes of high-energy water flow. The ORCs carried by rolling movement at the bottom of dense flow deposits first, with a typical feature of very low textural maturity for short-distance transportation (Figure 8C,F-I). Subsequently, some of the ORCs lifted by turbulence will overcome the limitation of buoyancy and deposit individually or in groups, which orient in the long-axis direction (Figure 8D,E,J). The ORCs, carried by high-dense flow far and modified strongly, deposit with the weakening of flow energy and transporting capacity (Figure 8B).

\section{Discussion}

\subsection{Occurrence and Classification}

The development of ORCs in coal-bearing sandstone is an important geological phenomenon which cannot be ignored. The occurrence of ORCs is not only influenced by the transportation of water 
flow, but also related to their own composition $[2,12,30]$. The hydrodynamic conditions of the water flow control the transportation process of ORCs (including the transportation ways, the transportation distance and the reworking intensity), which determines the final sedimentary style of ORCs, specific performances: (1) Some rolling transported ORCs have a short transportation distance and low degree of re-working within the dense flow, chaotically accumulating above the erosion surface with low texture maturity (Figure 9J-L). (2) The jumping transported ORCs are subjected to the strong hydrodynamic forces. Some large and intact ORCs are caught in the rapidly deposited sandy sediments leading to the severe plastic deformation (Figure 9G-I); some ORCs that "survived" from the actions of water flow and the collisions of grains (mostly sandy sediments) are small-sized but numerous with good sorting and roundness (Figure 9D-F); but the others are completely disintegrated during the transportation. (3) Some suspended and lightweight ORCs are transported over long distance with relatively weak reworking degree, and deposited as thin interlayers together with fine-grained sediments (mainly silts and clays) under weak hydrodynamic conditions (Figure 9A-C). The composition of ORCs also has an important influence on their susceptibility to mechanical disintegration [30]. The ORCs are mainly composed of higher plant debris Under the action of water flow, some muddy ORCs can be completely disintegrated into clay particles after undergoing mechanical attrition and disintegration; while higher plant fragments only change from large to small particles.

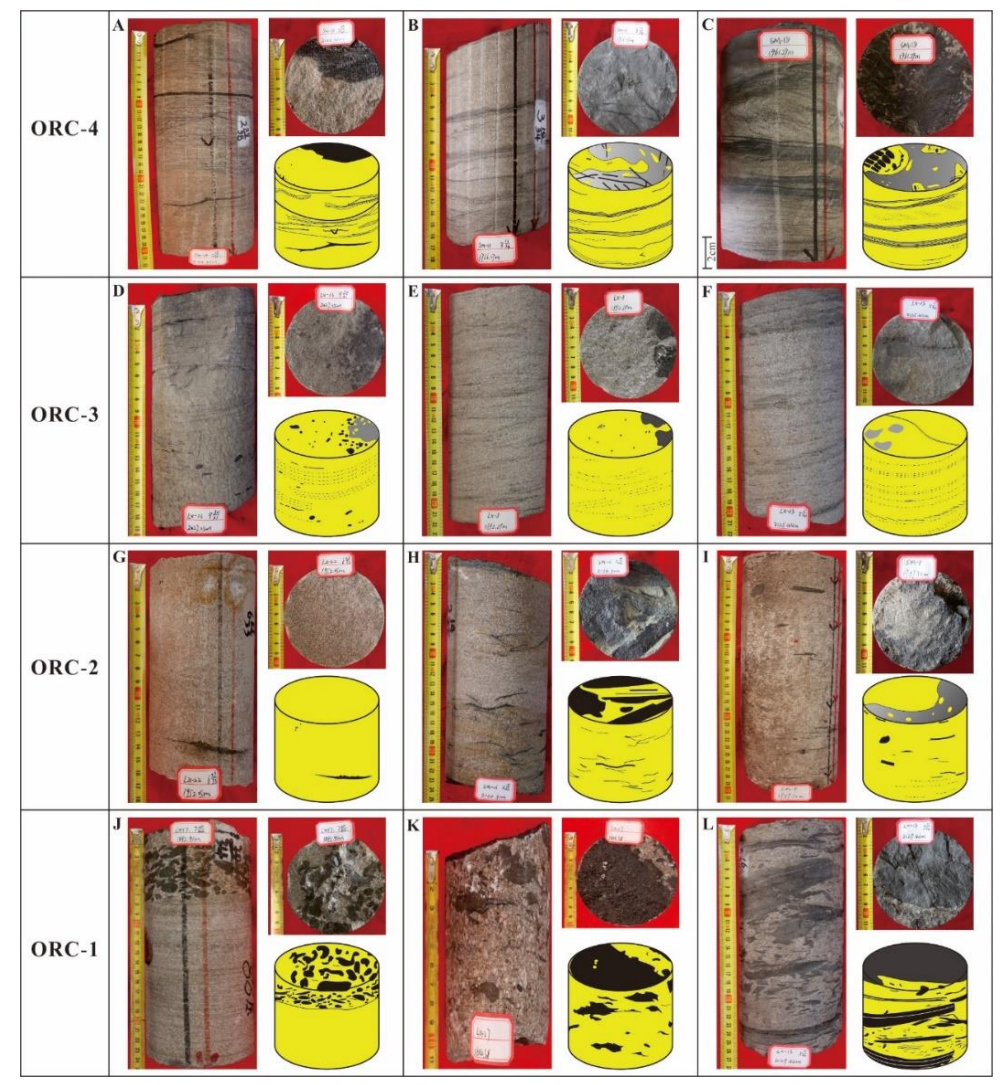

Figure 9. Typical core photos and 3D sketches of 4 types of the organic-rich clasts in the coal-bearing sandstone strata. Abbreviations: ORC-1 = Diamictic organic-rich clasts $(\mathbf{J}-\mathbf{K})$, ORC-2 = Floating organic-rich clasts (G-I), ORC-3 = Loaded lamellar organic-rich clasts (D-F), ORC-4 = Thin interlayer organic-rich clasts (A-C).

The classification of ORCs proposed here is based on considerations of their occurrence and the characteristics of hosting sediments. The characteristics given in Figure 8 and Table 2 are designed to aid in identification and interpretation with different types of ORCs. The energy of water flow changes dynamically, resulting in its different transportation mechanism at different stages $[5,12,69]$. 
Under a range of its processes, the vertical distribution characteristic of ORCs in coal-bearing sandstone confirms to the law of mechanical sedimentary differentiation. As the energy and transporting capacity of single water flow changes from strong to weak, the sedimentary sequences of ORCs can be concluded from the bottom up as follows: diamictic organic-rich clasts (ORC-1), floating organic-rich clasts (ORC-2), loaded lamellar organic-rich clasts (ORC-3) and thin interlayer organic-rich clasts (ORC-4, listed in Table 2, Figure 9). From ORC-1 to ORC-4, the grain size of their hosting sandy sediments shows a change from coarse to fine (Figure 9), which also confirms a vertical differentiation of ORCs. However, these four types of ORCs can occur differently in different facies associations or not developed originally in part, depending on the actual conditions in a special geological environment.

Table 2. Classification of the organic-rich clasts in the studied coal-bearing tight sandstone.

\begin{tabular}{|c|c|c|c|c|c|}
\hline $\begin{array}{l}\text { Style } \\
\text { Code }\end{array}$ & Style Name & $\begin{array}{c}\text { Features of ORCs in } \\
\text { Sediment }\end{array}$ & Matrix & $\begin{array}{l}\text { Transportation } \\
\text { Distance }\end{array}$ & $\begin{array}{c}\text { Part of } \\
\text { Single } \\
\text { Sand Body }\end{array}$ \\
\hline ORC-1 & $\begin{array}{l}\text { Diamictic } \\
\text { organic-rich } \\
\text { clasts }\end{array}$ & $\begin{array}{c}\text { Shape: irregular, } \\
\text { lath-shaped, rip-up, } \\
\text { angular to sub-rounded } \\
\text { Distribution: chaotic } \\
\text { distribution } \\
\text { Size: particle size varies } \\
\text { from granule to cobble }\end{array}$ & $\begin{array}{l}\text { A complete range } \\
\text { from gravel to clay, } \\
\text { poorly sorted, } \\
\text { massive }\end{array}$ & $\begin{array}{l}\text { In-situ or } \\
\text { a close distance }\end{array}$ & Bottom part \\
\hline ORC-2 & $\begin{array}{l}\text { Floating } \\
\text { organic-rich } \\
\text { clasts }\end{array}$ & $\begin{array}{l}\text { Shape: angular to } \\
\text { sub-rounded, commonly } \\
\text { irregular deformation as } \\
\text { wrapped or squeezed } \\
\text { Distribution: isolated or } \\
\text { scattered, imbrication, } \\
\text { long axis of clasts } \\
\text { parallel to sub-parallel to } \\
\text { bedding } \\
\text { Size: pebble to cobble, } \\
\text { particle size greater than } \\
1 \mathrm{~cm}\end{array}$ & $\begin{array}{l}\text { Medium to } \\
\text { coarse-grained, } \\
\text { well sorted, } \\
\text { Clay-poor,unstratified } \\
\text { or structureless }\end{array}$ & $\begin{array}{l}\text { A short } \\
\text { distance }\end{array}$ & $\begin{array}{c}\text { Middle and } \\
\text { lower part }\end{array}$ \\
\hline ORC-3 & $\begin{array}{c}\text { Loaded } \\
\text { lamellar } \\
\text { organic-rich } \\
\text { clasts }\end{array}$ & $\begin{array}{l}\text { Shape: sub-rounded to } \\
\text { rounded, high sphericity } \\
\text { Distribution: } \\
\text { Distributed at } \\
\text { the bottom of the lamina, } \\
\text { poor continuity } \\
\text { Size: granule to pebble }\end{array}$ & $\begin{array}{c}\text { Fine to } \\
\text { coarse-grained, } \\
\text { well sorted, } \\
\text { Clay-poor, parallel } \\
\text { bedding, cross } \\
\text { bedding, wavy } \\
\text { bedding }\end{array}$ & $\begin{array}{l}\text { A moderate } \\
\text { distance }\end{array}$ & $\begin{array}{c}\text { Middle and } \\
\text { upper part }\end{array}$ \\
\hline ORC-4 & $\begin{array}{l}\text { Thin interlayer } \\
\text { organic-rich } \\
\text { clasts }\end{array}$ & $\begin{array}{l}\text { Shape: sub-angular to } \\
\text { rounded, flakelet } \\
\text { Distribution: in } \\
\text { the form of multiple } \\
\text { lamellar aggregates, } \\
\text { wavy or horizontal, good } \\
\text { continuity } \\
\text { Size: mainly granule, } \\
\text { occasional } \\
\text { centimeter-sized clasts } \\
\text { are plant fragments } \\
\text { (such as stems or leaves) }\end{array}$ & $\begin{array}{l}\text { Very Fine to fine } \\
\text { grained, well } \\
\text { sorted, clay-rich, } \\
\text { lamination }\end{array}$ & A long distance & Top part \\
\hline
\end{tabular}

\subsection{Formation Mechanism}

The Upper Paleozoic sedimentary period in the Ordos Basin is in the background of transgression, and ORC is generated under the water action from rivers, tides, waves, and episodically floods and debris flows (Figure 10). The formation process of ORC underwater flow can be distinguished into 
four stages in sequence: (1) Original sedimentation of organic matter and fine-grained sediments to form source; (2) detachment of organic-rich sediments under hydrodynamism, which includes two main mechanisms: one is the basal erosion resulting in high-energy water flow, and the other is the instability slope failure triggered by water flow vibration; (3) transportation and reworking by water flow and water-transported debris; among them, the reworking is a dynamic process, including multiple crushing, deformation (such as squeezing squashing folding pressing), sorting, rounding; (4) allogenic re-deposition [1,2]. The initial failure products of organic-rich sediments are irregular ORC blocks, while transportation by water flow is the determinant of the difference in ORC deposition characteristics $[1,2,30]$. Based on this, we propose that the formation mechanisms of ORC could be classified into: long-term altering of continuous water flow (such as fluvial water, tide, etc.) and short-term water flow acting triggered by sudden events (such as flood, debris flow, etc.).

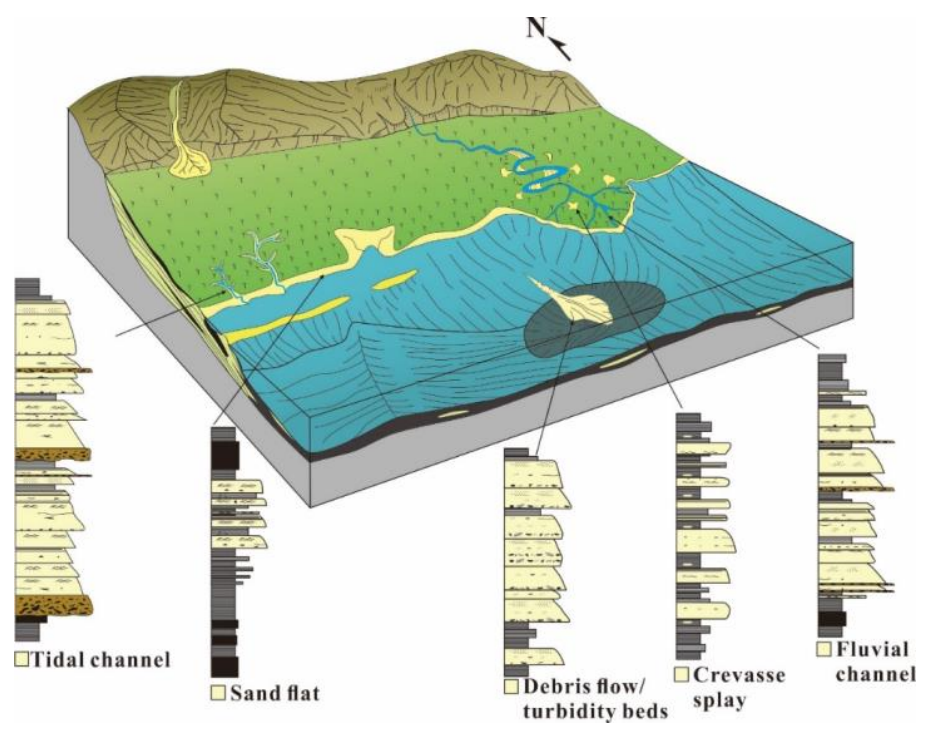

Figure 10. Schematic sedimentary model of the organic-rich clasts in the coal-bearing sandstone strata in the northeastern margin of the Ordos Basin.

Regarding the first instance, the sedimentary characteristics of the residual ORC in the coal-bearing sandstone are the results of modification by the continuous or periodic water flow within a long period. In the process of transportation, ORCs undergo a series of dynamic processes including liquefying, crushing, squeezing, squashing, winnowing, folding and pressing in the long-term and repeatedly, resulting in broken-up of most pre-formed ORC into smaller fragments. The vertical differentiation between sandy sediments and organic-rich debris is obvious, which suggests that the evolution of water flow from high-density, high-energy to low-density; low-energy turbulence is a slow but gradual process. In the lower flow regime, the suspended ORC often deposits as thin interlayers with fine-grained muddy sediments, usually neglecting the role of ORC previously.

Interestingly, the modification degree of transport on ORC in the short-term water flow is less than the first type, typically low textual maturity. The temporary water flow is often triggered by a sudden event, which may be flood, earthquake, storm or tsunami. This water flow tends to be high-energy, high-density and dissipates energy rapidly (often lasting only a few hours) for breaking through the confined state, resulting in the weak re-working on ORC during transportation. In this study, the thick-bedded diamictic ORC deposited in the early stage of the high-energy water flow energy weakening. Where after, some ORCs were captured during the deposition of sandy sediments, transported in skipping. Finally, the ORCs contained in the suspension transport formed thin interlayers in a lower flow regime, but it is seldom recognized. There are two major reasons: the basal erosion by the new sudden water flow or continuous deposition with fine-grained deposits in the absence of new sudden water flow. 


\section{Conclusions}

(1) It is proposed to use the descriptive vocabulary organic-rich clasts (ORC) to collectively represent carbonaceous fragments, carbonaceous mudstone clasts, shale clasts, dark mudstone clasts and plant fragments developed in coal-bearing sandstones.

(2) A total of five sedimentary environments of ORC were identified, including fluvial channels, crevasse fans, tidal channels, sand flats, and subaqueous debris flow deposits.

(3) The occurrence of ORCs in coal-bearing sandstones is not only controlled by the changes of the water flow during transportation, but also related to the decomposition resistance of their components. After a series of processes during water flow transport, ORCs shows the characteristic of obvious mechanical differentiation in the vertical direction. Based on this, we propose that ORCs can be classified into four types: diamictic organic-rich clasts, floating organic-rich clasts, loaded lamellar organic-rich clasts, and thin interlayer organic-rich clasts.

(4) The changes in water flow energy during transportation play a controlling role in the formation of ORCs. We have summarized two formation mechanisms of ORCs in coal-bearing sandstones, including the long-term altering of continuous water flow and the short-term water flow acting triggered by sudden events.

Author Contributions: Conceptualization, G.Y.; methodology, G.Y.; software, G.Y.; validation, G.Y., W.H., J.Z. and N.S.; formal analysis, G.Y.; investigation, N.S.; resources, G.Y.; data curation, G.Y.; writing-original draft preparation, G.Y.; writing - review and editing, W.H. and J.Z.; visualization, G.Y.; supervision, W.H.; project administration, W.H.; funding acquisition, W.H. All authors have read and agreed to the published version of the manuscript.

Funding: This research was financially supported by the National Major Science and Technology Projects of China (No.2016ZX05066001-003) and National Natural Science Foundation of China (No. U1910205).

Acknowledgments: Special thanks are given to China United Coalbed Methane Corporation for providing the studied samples and data.

Conflicts of Interest: The authors declare no conflicts of interest.

\section{References}

1. Knight, J. Morphology and palaeoenvironmental interpretation of deformed soft-sediment clasts: Examples from with Late Pleistocene glacial outwash, Tempo Valley, Northern Ireland. Sediment. Geol. 1999, 128, 293-306. [CrossRef]

2. Knight, J. Significance of soft-sediment clasts in glacial outwash, Puget Sound, USA. Sediment. Geol. 2009, 220, 126-133. [CrossRef]

3. Haas, W. Formation of Clay Balls. J. Geol. 1927, 35, 150-157. [CrossRef]

4. Karcz, I. Mud pebbles in a flash floods environment. J. Sediment. Res. 1969, 39, 333-337. [CrossRef]

5. Kneller, B.; Branney, M. Sustained high-density turbidity currents and the deposition of thick massive sands. Sedimentology 1995, 42, 607-616. [CrossRef]

6. Allen, J. Reworking of muddy intertidal sediments in the severn estuary, Southwestern U.K.-A preliminary survey. Sediment. Geol. 1987, 50, 1-23. [CrossRef]

7. Goldschmidt, P. Armoured and unarmoured till balls from the Greenland Sea floor. Mar. Geol. 1994, 121, 121-128. [CrossRef]

8. Selby, I.; Evans, N. Origins of mud clasts and suspensions on the seabed in Hong Kong. Cont. Shelf Res. 1997, 17, 57-78. [CrossRef]

9. Knight, J. Processes of soft-sediment clast formation in the intertidal zone. Sediment. Geol. 2005, 181, $207-214$. [CrossRef]

10. Southern, S.; Patacci, M.; Felletti, F.; McCaffrey, W. Influence of flow containment and substrate entrainment upon sandy hybrid event beds containing a co-genetic mud-clast-rich division. Sediment. Geol. 2015, 321, 105-122. [CrossRef]

11. Gao, Z.; Zhou, C.; Feng, J.; Wu, H.; Li, W. Mechanism and sedimentary environment of the muddy gravel concomitant with thick layer sandstone of Cretaceous in Kuqa depression. Acta Petrol. Sin. 2016, 37, 996-1010. (In Chinese) [CrossRef] 
12. Li, S.; Li, S.; Shan, X.; Gong, C.; Yu, X. Classification, formation, and transport mechanisms of mud clasts. Int. Geol. Rev. 2017, 59, 1-12. [CrossRef]

13. Bell, H. Armored Mud Balls: Their Origin, Properties, and Role in Sedimentation. J. Geol. 1940, 48, 1-31. [CrossRef]

14. Dickas, A.; Lunking, W. The origin and destruction of armored mud balls in a fresh-water lacustrine environment, Lake Superior. J. Sediment. Res. 1968, 38, 1366-1370. [CrossRef]

15. Little, R. Lithified Armored Mud Balls of the Lower Jurassic Turners Falls Sandstone, North-Central Massachusetts. J. Geol. 1982, 90, 203-207. [CrossRef]

16. Diffendal, R. Armored Mud Balls and Friable Sand Megaclasts from a Complex Early Pleistocene Alluvial Fill, Southwestern Morrill County, Nebraska. J. Geol. 1984, 92, 325-330. [CrossRef]

17. Mather, A.; Stokes, M.; Pirrie, D.; Hartley, R. Generation, transport and preservation of armoured mudballs in an ephemeral gully system. Geomorphology 2008, 100, 104-119. [CrossRef]

18. Wani, H.; Dar, S.; Mondal, M. Occurrence of Unusual Unarmored, Unlithified Fossil Mud Balls in Plio-Pleistocene Lacustrine Sediments, Kashmir, India. J. Geol. 2017, 125, 479-486. [CrossRef]

19. Ghandour, I.; Al-Washmi, H.; Haredy, R. Gravel-Sized Mud Clasts on an Arid Microtidal Sandy Beach: Example from the Northeastern Red Sea, South Al-Wajh, Saudi Arabia. J. Coastal Res. 2013, 291, 110-117. [CrossRef]

20. Henares, S.; Arribas, J.; Cultrone, G.; Viseras, C. Muddy and dolomitic rip-up clasts in Triassic fluvial sandstones: Origin and impact on potential reservoir properties (Argana Basin, Morocco). Sediment. Geol. 2016, 339, 218-233. [CrossRef]

21. Allen, J. Sedimentary Structures, their Character and Physical Basis; Elsevier: Amsterdam, The Netherlands, 1982.

22. Kortekaas, S.; Dawson, A. Distinguishing tsunami and storm deposits: An example from Martinhal, SW Portugal. Sediment. Geol. 2007, 200, 208-221. [CrossRef]

23. Goff, J.; Chagué-Goff, C.; Nichol, S.; Jaffe, B.; Dominey-Howes, D. Progress in palaeotsunami research. Sediment. Geol. 2012, 243-244, 70-88. [CrossRef]

24. Gibbard, P.; Boreham, S.; Roe, H.; Burger, A. Middle Pleistocene lacustrine deposits in eastern Essex, England and their paleogeographical implications. J. Quat. Sci. 2015, 11, 281-298. [CrossRef]

25. Ishizawa, T.; Goto, K.; Yokoyama, Y.; Miyairi, Y.; Sawada, C.; Takada, K. Reducing the age range of tsunami deposits by, $14 \mathrm{C}$ dating of rip-up clasts. Sediment. Geol. 2018, 364, 334-341. [CrossRef]

26. Plint, A. Slump blocks, intraformational conglomerates and associated erosional structures in Pennsylvanian fluvial strata of eastern Canada. Sedimentology 1986, 33, 387-399. [CrossRef]

27. Poll, H.; Patel, I. Slump blocks, intraformational conglomerates and associated erosional structures in Pennsylvanian fluvial strata of eastern Canada. Sedimentology 1989, 36, 137-145. [CrossRef]

28. Gibling, M.; Tandon, S. Erosional marks on consolidated banks and slump blocks in the Rupen River, north-west India. Sedimentology 1997, 44, 339-348. [CrossRef]

29. Smith, N. Flume experiments on the durability of mud clasts. J. Sediment. Res. 1972, 42, 378-383. [CrossRef]

30. Woźniak, P.; Pisarska-JamroźY, M. Debris flows with soft-sediment clasts in a Pleistocene glaciolacustrine fan (Gdańsk Bay, Poland). Catena 2018, 165, 178-191. [CrossRef]

31. Petrascheck, W. Das Vorkommen von SteinkohlengerIllen in einen Karbonsandstein. Verh. Kais. Königlich Geol. Reichsanst. 1909, 16, 380-386. (In German)

32. Brune, A. Einlagerungen fremder Gesteine in Steinkohlenflo"tzen unter besonderer Berfcksichtigung Ausffllung von Erosionhohlra“umen. Glfckauf 1930, 66, 1157-1165. (In German)

33. Cross, A. The geology of Pittsburgh coal: Stratigraphy, petrology, origin and composition, and geologic interpretation of mining problems. In Proceedings of the Second Conference on Origin and Constitution of Coal, Crystall Cliffs, NS, Canada, 18-20 June 1952; pp. 32-111.

34. Dembowski, Z.; Jachowitz, A. Otoczaki i okruchy we gla na wto'rnym zloyu w piaskowcach warstw orzeskich i yaziskich wiercenia Mie dzyrzecze IG 2. Biuletin Inst. Geol. 1964, 184, 125-176, (In Polish with English summary).

35. Gayer, R.; Pešek, J. Cannibalisation of coal measures in the south Wales coalfield-significance for foreland basin evolution. Proc. Ussher Soc. 1992, 8, 44-49. 
36. Daněk, V.; Pešek, J.; Valterová, P. Coal clasts in the Bolsovian (Westphalian C) sequence of the Kladno-Rakovník continental basin (Czech Republic): Implications for the timing of maturation. Pol. Geol. Inst. Spec. Pap. 2002, 7, 63-78.

37. Pešek, J.; Sýkorová, I. A review of the timing of coalification in the light of coal seam erosion, clastic dykes and coal clasts. Int. J. Coal Geol. 2006, 66, 13-34. [CrossRef]

38. Paszkowski, M.; Lachowicz, H.; Michalik, M.; Teller, L.; Uchman, A.; Urbanek, Z. Composition, age and provenance gravel-sized clast from the Upper Carboniferous of the Upper Silesian Coal basin (Poland). Stud. Geol. Pol. 1995, 108, 45-126.

39. Gayer, R.; Pešek, J.; Sýkorová, I.; Valterová, P. Coal clasts in the upper Westphalian sequence of the South Wales coal basin: Implication for the timing of maturation and fracture permeability. Geol. Soc. Lond. Spec. Publ. 1996, 109, 103-120. [CrossRef]

40. Dai, J. Coal-derived gas theory and its discrimination. Chin. Sci. Bull. 2018, 63, 1290-1305. [CrossRef]

41. Dai, J.; Ni, Y.; Liao, F.; Hong, F.; Yao, L. The significance of coal-derived gas in major gas producing countries. Petrol. Explor. Dev. 2019, 46, 435-450. [CrossRef]

42. Zou, C. Unconventional Petrolume Geology; Elsevier: Amsterdam, The Netherlands, 2013.

43. Fu, J.; Fan, L.; Liu, X.; Huang, D. Gas accumulation conditions and key technologies for exploration and development of Sulige gas field. Petrol. Res. 2018, 3, 91-109. [CrossRef]

44. Yang, Y.; Zhong, J.; Sun, Y.; Wang, J.; Fan, L.; Ni, L.; Zhao, Y. Discussion on characteristics and accumulation mechanisms of "proximal-generation and proximal-storage" type tight sandstone gas accumulations in Shuixigou Group, Turpan-Hami Basin. J. China Univ. Petrol. 2014, 38, 34-41. (In Chinese) [CrossRef]

45. Qin, Y. Research progress of symbiotic accumulation of coal measure gas in China. Nat. Gas Ind. B 2018, 5, 466-474. [CrossRef]

46. Saller, A.; Lin, R.; Dunham, J. Leaves in turbidite sands: The main source of oil and gas in the deep-water Kutei Basin, Indonesia. AAPG Bull. 2006, 90, 1585-1608. [CrossRef]

47. Baudin, F.; Disnar, J.R.; Martinez, P.; Dennielou, B. Distribution of the organic matter in the channel-levees systems of the Congo mud-rich deep-sea fan (West Africa). Implication for deep offshore petroleum source rocks and global carbon cycle. Mar. Petrol. Geol. 2010, 27, 995-1010. [CrossRef]

48. Wang, H.; Mo, X. An outline of the tectonic evolution of China. Episodes 1995, 18, 6-16. [CrossRef] [PubMed]

49. Zhao, J.; Zhang, W.; Li, J.; Cao, Q.; Fan, Y. Genesis of tight sand gas in the Ordos Basin, China. Org. Geochem. 2014, 74, 76-84. [CrossRef]

50. Yang, Y.; Li, W.; Ma, L. Tectonic and stratigraphic controls of hydrocarbon systems in the Ordos basin: A multicycle cratonic basin in Central China. AAPG Bull. 2005, 89, 255-269. [CrossRef]

51. Gao, X.; Wang, Y.; Ni, X.; Li, Y.; Wu, X.; Zhao, S.; Yu, Y. Recovery of tectonic traces and its influence on coalbed methane reservoirs: A case study in the Linxing area, eastern Ordos Basin, China. J. Nat. Gas Sci. Eng. 2018, 56, 414-427. [CrossRef]

52. Yang, M.; Liu, C.; Lan, C.; Liu, L.; Wang, J. Sequence Stratigraphy of Late Paleozoic Coal-Bearing Measures in Northeastern Ordos Basin. Acta Sediment. Sin. 2008, 12, 1005-1013. (In Chinese)

53. Xue, C.; Wu, J.; Zhong, J.; Zhang, S.; Zhang, B.; Hao, B.; Wang, D. Characteristics of the marine-terrigenous interdepositional shale: A case study of Taiyuan formation in Linxing area of Ordos basin. J. China Univ. Min. Technol. 2019, 48, 870-881. (In Chinese) [CrossRef]

54. Guo, Y.; Liu, H.; Quan, B.; Wang, Z.; Qian, H. Late Paleozoic sedimentary system and paleogeographic evolution of Ordos area. Acta Sediment. Sin. 1998, 16, 44-51. (In Chinese)

55. Guo, D. The Study of Sedimentary System of Upper Paleozoic in East Ordos Basin. Ph.D. Thesis, Northwest University, Xi'an, China, 2009. (In Chinese).

56. Wang, Y.; Chen, S.; Liang, H.; Wang, J.; Li, T. Sedimentary Facies and Their Evolution in the Upper Paleozoic of Baode Area,Ordos Basin. Acta Sediment. Sin. 2016, 34, 775-784. (In Chinese) [CrossRef]

57. Shi, J.; Huang, W.; Lv, C.; Cui, X. Geochemical characteristics and geological significance of the Upper Paleozoic mudstones from Linxing area in Ordos Basin. Acta Petrol. Sin. 2018, 39, 876-889. (In Chinese) [CrossRef]

58. Fu, N.; Yang, S.; He, Q.; Xu, W.; Lin, Q. High-efficiency reservoir formation conditions of tight sandstone gas in Linxing-Shenfu blocks on the east margin of Ordos Basin. Acta Petrol. Sin. 2016, 37 (Suppl. 1), 111-120. (In Chinese) [CrossRef] 
59. Li, Y.; Wang, Z.; Pan, Z.; Niu, X.; Yu, Y.; Meng, S. Pore structure and its fractal dimensions of transitional shale: A cross-section from east margin of the Ordos Basin, China. Fuel 2019, 241, 417-431. [CrossRef]

60. Xie, Y.; Meng, S.; Gao, L.; Sun, X.; Duan, C.; Wang, H. Assessments on potential resources of deep coalbed methane and compact sandstone gas in Linxing Area. Coal Sci. Technol. 2015, 43, 21-24, 28. (In Chinese) [CrossRef]

61. Luo, J.; Shi, C.; Li, B.; Li, Z.; Li, J.; Han, Y.; Zhao, J.; Du, J.; Dai, Y.; Yang, B. Sediment provenance of Chang 6 and Chang 8 oil-bearing of Yanchang formation in the Xi Feng area and peripheral of Ordos Basin: Evidence from rock geochemistry. Sci. China Ser. D 2007, 37, 62-72. (In Chinese) [CrossRef]

62. Liao, C.; Zhang, Y.; Wen, C. Structural Styles of the Eastern Boundary Zone of the Ordos Basin and Its Regional Tectonic Significance. Acta Geol. Sin. 2007, 81, 466-474. (In Chinese)

63. International Committee for Coal and Organic Petrology (ICCP). The new inertinite classification (ICCP System 1994). Fuel 2001, 80, 459-471. [CrossRef]

64. Sykorova, I.; Pickel, W.; Christanis, K.; Wolf, M.; Taylor, G.H.; Flores, D. Classification of huminite-ICCP system 1994. Int. J. Coal Geol. 2005, 62, 85-106. [CrossRef]

65. Pickel, W.; Kus, J.; Flores, D.; Kalaitzidis, S.; Christanis, K.; Cardott, B.J.; Misz-Kennan, M.; Rodrigues, S.; Hentschel, A.; Hamor-Vido, M.; et al. Classification of liptinite-ICCP system 1994. Int. J. Coal Geol. 2017, 169, 40-61. [CrossRef]

66. Miall, A. A review of the braided-river depositional environment. Earth Sci. Rev. 1977, 13, 1-62. [CrossRef]

67. Wang, S.; Shao, L.; Wang, D.; Sun, Q.; Sun, B.; Lu, J. Sequence stratigraphy and coal accumulation of Lower Cretaceous coal-bearing series in Erlian Basin, northeastern China. AAPG Bull. 2019, 103, 1653-1690. [CrossRef]

68. Zhong, J.; Wen, Z.; Wang, G.; Wang, X.; Rao, M.; Li, Y.; Ni, J.; Shen, X. Influences of the Current Breaking of the Yellow River on the Anomalous Vertical Development and Evolution of the River Course. Geol. Rev. 2003, 49, 616-621. (In Chinese)

69. Pisarska-Jamroży, M. Transitional deposits between the end moraine and outwash plain in the Pomeranian glaciomarginal zone of NW Poland: A missing component of ice-contact sedimentary models. Boreas 2006, 35, 126-141. [CrossRef]

(C) 2020 by the authors. Licensee MDPI, Basel, Switzerland. This article is an open access article distributed under the terms and conditions of the Creative Commons Attribution (CC BY) license (http://creativecommons.org/licenses/by/4.0/). 